\title{
Eco-Lodges and Tourist Infrastructure Development in and Around Abijata Shalla Lakes National Park; From the Perspective of Evaluating their Sustainability
}

\author{
Zerubabel Worku \\ GIZ- Biodiversity and Forestry Programme (BFP), P.O. Box 100009, Addis Ababa, Ethiopia \\ Tsion Mohammed \\ Department of Ecotourism and Cultural Heritage Management, Hawassa University, Wondo Genet College of \\ Forestry and Natural Resources, Shashamene, Ethiopia. P.O. Box 128, Shashamene, Ethiopia
}

\begin{abstract}
We tried to identify Ecolodges and other tourist infrastructures in and around Abijata Shalla Lakes National Park, the central part of Ethiopian great rift valley and evaluate their sustainability based on ecological, social and economic efficiency. The study was conducted on April 2017 using both qualitative and quantitative information sources in which the data is gathered by direct observation, secondary data from a wide range of sources within the current literatures on the topic and an in-depth interview. The collected data then analyzed and interpreted by descriptive and explanatory methods of analysis to come up with results and discussions. A total of fifteen lodges were recorded in the area, of which two of them are located inside the park while thirteen of the lodges are located outside the park. However, the survey is conducted only on eight active/functioning lodges at the time of data collection only focusing on operational phase excluding the pre-development and the construction phase. All the surveyed lodges are within $22 \mathrm{kms}$ radius, except one lodge which is found in $82 \mathrm{~km}$ away from the head quarter of the park. Six of the lodges can be reached with only three kilo-meters off road driving while the rest two are in 14 and $17 \mathrm{kms}$ off road driving. In staffing, $94.8 \%$ of the employees are local peoples while only $5.2 \%$ of them are from other places. Electricity is the major energy source, generator is used as a backup, candles are often used for different purposes and one lodges uses solar energy. Public water is a source for a clean water supply and water from the lakes with chemical treatment, but one lodge uses ground water in addition to public and lake water. All lodges have septic tank for waste treatment and none of the lodges recycle. Generating optional energy is recommendable through proper utilization of resources by recycling as it plays a great role and is basic principle in sustainability.
\end{abstract}

Keywords: Ecological, Economic Social, Sustainable, Tourism

DOI: $10.7176 / \mathrm{JTHS} / 45-02$

Publication date: December $31^{\text {st }} 2019$

\section{INTRODUCTION}

Tourism is the sum of the phenomena and relationship arising from the travel and stay of non-residents, in so far, they don't lead permanent residence and are not connected with any earning activity (UNWTO 2011). Tourism can have different types. Since the 1980s, ecotourism has been considered a critical endeavor by environmentalists, so that future generations may experience destinations relatively untouched by human intervention. Several university programs use this description as the working definition of ecotourism. Ecotourism, is a niche market in the large tourism business, is a form of tourism involving visiting fragile, pristine, and relatively undisturbed natural areas, intended as a low-impact and often small-scale alternative to standard commercial mass tourism. It means responsible travel to natural areas conserving the environment and improving the well-being of the local people (TIES, 2004).

Its purpose may be to educate the traveler, to provide funds for ecological conservation, to directly benefit the economic development and political empowerment of local communities, or to foster respect for different cultures and for human rights. Besides, Ecotourism is "Environmentally responsible travel to natural areas, to enjoy and appreciate nature (and accompanying cultural features, both past and present) that promote conservation, have a low visitor impact and provide for beneficially active socio-economic involvement of local peoples" (zmescience.com). The first thing ecotourism implies is a level of awareness from the tourists. The tourists should be aware the impact both on the local environment and on the local community, and should try, within reasonable limits, to reduce this impact. As a growing number of eco-tourists plan their holidays around authentic natural and cultural experiences, they will increasingly seek accommodations, such as eco-lodges, that reflect the main principles of ecotourism.

\subsection{History of Tourism Development in Ethiopia}

Ethiopia has a long history of conservation. The first recorded indigenous conservation-oriented activity took place 
during the reign of Emperor Zerea Yacob (1434-1468) (Amare, A. 2015). Later, in the early 19th century the wildlife conservation was only for large and flagship animals. For example, Emperor Menelik II on 1908 amended the first regulation, against young elephant hunting by peoples. Then, in 1960's based on the United Nations Scientific, Educational and Cultural Organization (UNESCO) suggestion to the country, Ethiopian Wildlife Conservation Organization (EWCO) was established in 1964 under Ministry of Agriculture. During this time two protected areas namely; Awash National Park and Simien Mountains National Park were established. The former EWCO changed its name to Ethiopian Wildlife Conservation Authority (EWCA) and formally re-established since 2008 under Ministry of Culture and Tourism aimed to manage and conserve the protected areas of the country.

The country's geology, archeological sites and landscape as well as cultural diversity have been contributed for tourism development and promotion. However, the wildlife tourism solely dependent on protected areas, primarily national parks and sanctuaries of the country. Promotion of ecotourism assumes that people come to visit Ethiopia not merely for enjoying themselves, but to gain knowledge and appreciation of the country's geographical and natural features, of its peoples and their interaction with their environment, to gain better understanding of the way developments affects the environment and how problems may be dealt with. Tourism in Ethiopia has always involved features of ecotourism. People who visit historic route are, of also interested in the physical features of these areas and in the extent to which they are being protected.

In recent years visitors have increased to other areas of major environmental interest; Simein Mountains, Bale Mountains, the Rift valley lakes and especially to the Omo valley and other parts of the southwest. Besides, ecolodge developments begun at areas which are reach in natural resources including protected areas. Eco-lodges in protected areas of Ethiopia include; Awash falls lodge at Awash national park, simein mountains lodge at simein mountains national park, Dinsho and Bale mountains lodge at Bale mountains national park, 10,000 flamingos and Ethio-samell lodges at Abijata shalla lakes national park can be mentioned as major examples.

\subsection{The Concept of Eco Lodges}

The International Ecotourism Society (TIES) defines eco-lodges as including three main components: conservation of neighboring lands, benefits to local communities, and interpretation to both local populations and guests. Ecolodges are an exciting and potentially extremely viable strategy for achieving all the tenants of ecotourism, and more specifically community based eco-tourism. The authors of the Eco-Lodge Footprint and Justification for Biodiversity Conservation study mapped the locations of nature-based lodges in 60 countries (chosen based on their high concentration of nature-based lodges) 84 percent are in biodiversity hotspot areas, as defined by Conservation International (www.biodiversityhotspots.org).

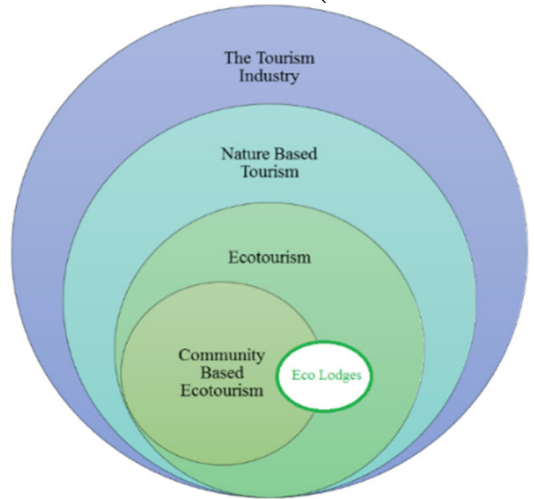

Figure 1. The tourism industry and ecolodges

The high number of eco-lodges and nature-based lodges located in or near protected areas, or areas of high biodiversity value, demonstrates the need for lodges to maintain sound environmental standards and practices. As the study, at www.ifc.org/ebfp this types of lodges should have ecological, socio cultural and economic sustainability in all the three phases of eco-lodge development and operations: The pre-development phase, which includes an overall assessment of the project proposal and the obtaining of appropriate permission and development support from local communities and regulatory agencies; The construction phase, which includes the actual development of the lodge and surrounding area; and the operations phase, which includes the ongoing, daily operations of the business and programs of running an eco-lodge, from tracking energy efficiency, to local community benefits and interpretation. 


\subsection{Sustainability}

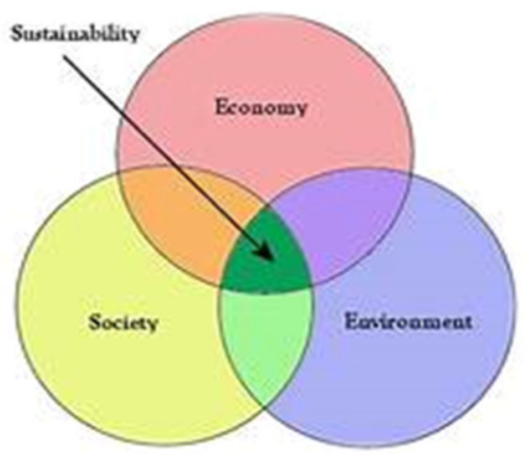

Figure 2. The notion of sustainability under the three pillars
The concept of sustainability continues to expand in scope. In 2000, the Earth Charter broadened the definition of sustainability to include the idea of a global society "founded on respect for nature, universal human rights, economic justice, and a culture of peace." To achieve these lofty goals, humans will have to re-examine their policies on: Environmental protection, Social responsibility and Economic practice (Sustainability Degrees.com).

Sustainability is understood from the proper use of natural resources and conservative strategies to transfer the resources for the coming generation. In this context, destinations who use alternative energy sources for service delivery and offers activities that doesn't need to consume the natural resources can be judged as sustainable destinations. Whereas, those who are purely dependent on the natural resources and doesn't concern on the conservation of the resources while making their major aim profit maximization cannot be taken as sustainability. Arising from the complexity of the situation, the present study is accompanied by aiming to assess Eco-lodges and tourist infrastructure development in and around Abijata Shalla lakes national park, Central rift valley of Ethiopia; from the perspective of evaluating their sustainability.

\section{MATERIALS AND METHODS}

\subsection{The Study Area}

Location: Abijata Shalla Lakes National Park (ASLNP) is located in the central portion of the Ethiopian Great Rift-Valley, in Oromia Region, 207Km South of Addis Ababa via Shashemane asphalt road (Hirut Sintayehu. 2012). Geographically the park is located between $7^{0} 22^{\prime} 4.8^{\prime \prime}$ to $7^{0} 42^{\prime} 47.7^{\prime \prime} \mathrm{N}$ and longitudes $38^{0} 22^{\prime} 32.8^{\prime \prime}$ to $38^{0} 40^{\prime} 36.4^{\prime \prime} \mathrm{E}$ at an elevation ranging from $1540 \mathrm{~m}$ to $2075 \mathrm{~m}$ above sea level (Fekadu Tefera and Rezenom Almaw, 2002). The Abijata Shalla Lakes National Park encompass an area of $887 \mathrm{~km}^{2}$, of which $505 \mathrm{~km}^{2}$ is water body (principally by the alkaline lakes, Abijata, Shalla and Chitu) and their shorelines, and $382 \mathrm{~km}^{2}$ is land or terrestrial ecosystem, which comprise the acacia woodland, acacia bush land, scrubland and grassland vegetation and the rocky outcrops (Rezenom Almaw, 2012). The two lakes (Abijata and Shalla), are separated by three kilometers of hilly land (Bethlehem Abebe, 2013).

Geology and Climate: The rift floor is occupied by a series of large lakes fed by perennial rivers originating from adjacent/bordered highlands both to the east and west directions (Adem Gobena, 2008 citing of (Tenalem Ayenew, 2001)). Moreover, geological records from the area showed that there have been great changes the sizes of the lakes in the past years and other features of the park such as hot springs, cliffs, and lava cave (Adem Gobena, 2008). The soil of study area is often alluvial and very fine in nature, and is very susceptible to both wind and water erosion (Adem Gobena, 2008 citing of (Tolcha Regassa, 2005)) and it is maintained by the acacia-euphorbia woodland around the lakes (EWNHS, 1996). The climate of ASLNP falls within the ecological-climate zone III semi-arid (Rezenom Almaw, 2012). Rainfalls period is between March, April, June, and September, averaging $500 \mathrm{~mm}$. Average annual temperature is $20.10 \mathrm{C}$; with a mean maximum of $26.60 \mathrm{C}$ and mean minimum of $13.50 \mathrm{C}$ (EWNHS, 1996).

Flora and fauna: The park features, Semi-arid acacia woodland, bush land, shrub land and open plains; which are crucial components of the park ecosystem, keeping the highly fragile soil of the area intact. The major attractive fauna are bird species (Fekadu Tefera and Rezenom Almaw, 2002). As a Study by Rezenom Almaw (2002) 453 bird species (52.5\% of the country total) are found in this park. Additionally, Mammal species like; Grant's gazelle, Bohor Reedbuck, Warthog, Greater Kudu, Caracal, Colobus, Aardvark, Hyenas and Black-backed Jackals are common and widespread.

Socio-economy: The people who settled in and around the park are ethnic group of Oromo-Arsi. Pastorals and subsistence farming are mainly dominating the socio-economic conditions in ASLNP and the surrounding areas (Feyera Senbeta and Fekedu Tefera, 2001). Being among the major socio-economic problems, highly increasing size of population and livestock density, could account for the deterioration of the general situation of ASLNP. The park is unsuitable for agriculture and heavy grazing but the local people use it for these purposes (EWNHS, 1996).

\section{Methods}

Both qualitative and quantitative research designs were used for the better success of the study following Sigh (2004). Primary and secondary information sources have also been used; the primary data collection was made using direct observation (personal record) which is supported through Digital camera (Nikon D3200). Secondary data for this research has been collected from a wide range of sources within the current literatures on the topic. 
Additionally, In-depth interview was made for lodge managers/owners to obtain detail information after the identification of Eco-lodges at the area. Information gathered through informant interview, observation and review of secondary sources were analyzed qualitatively descriptive and explanatory methods of analysis to come up with results and discussions.

\section{RESULTS AND DISCUSSION}

The research basically focuses on assessment of the eco-lodges and tourist infrastructure developments that are in and around Abijata shalla lakes national park (ASLNP) and it tries to evaluate the development of destinations from being in line with one of the basic principle of ecotourism; sustainability. Therefore, the analysis mainly focused on the operational phase excluding the pre-development and the construction phase. As result, only 7 of the total eco-lodges are used as samples of the study. The eco-lodges that are used under this study are listed in the following tables with their distance from the park and functional status at the time of data collection. Except 10,000 flamingo's lodge and Ethio-Samell lodge, which is found adjacent to Lake Chitu and Lake Shalla inside the park all lodges are located surrounding Lake Langano which is outside the park. In addition to the lodges listed below; two lodges near to Sabana beach resort, another two lodges near langano lodge and one lodge near to borati resort in an approximately $9 \mathrm{~km}, 12 \mathrm{~km}$ and $14 \mathrm{~km}$ from the park head quarter (totally 5 lodges) which are under construction are not included in the analysis.

\subsection{ECO-LODGE AND TOURIST INFRASTRUCTURES DEVELOPMENT IN ASLNP (as of 2017)}

In addition to the buildings (Offices, Outposts, camp sites) and roads used for the park management, Two Ecolodges were recorded inside Abijata Shalla Lakes National park (Table 1). However only 10,000 flamingos lodge was surveyed since Ethio-samell lodge was under construction by the time of the data collection.

Table 1. Eco-lodges inside Abijata Shalla Lakes National park (ASLNP).

\begin{tabular}{|l|l|l|l|}
\hline No & Name of the lodge & Distance from the park HQ & Status \\
\hline $\mathbf{1}$ & 10,000 flamingos lodge & $82 \mathrm{kms}$ & Active \\
\hline $\mathbf{2}$ & Ethio-samell lodge & $9 \mathrm{kms}$ & under construction \\
\hline
\end{tabular}

\subsubsection{0,000 FLAMINGOS LODGE, ASLNP}

This is the only surveyed lodge that is found in ASLNP which is established two years ago by Belgian owner Jan Jackers who also owns a lodge named viewpoint lodge on Lake Babogaya, Bishoftu. The lodge is found $82 \mathrm{kms}$ away from the park and $62 \mathrm{kms}$ of the road is asphalt and $14 \mathrm{kms}$ gravel road.

Natural attractions and activities: three lakes (chitu, shalla and abijata), mountains (including the parks peak mount fike), wild mammals (76 mammal species), birds (462 bird species), captive ostrich's, hot springs (with boiling point of $97^{\circ} \mathrm{c}$ ), landscapes, caves, islands and viewpoints. Since the lake is alkaline swimming and beach games are not advised but outdoor playing ground, guided walks to both nearby lakes (shalla and chitu), bird watching and overall park visiting is available.

Accommodations: the lodge has 10 (ten) double bed rooms with extra beds on request. It also has one restaurant which can be used as conference room, camping is available both in the lodge and on selected camp sites of the park. All types of foods are available based the request of the guests.

Transportation: the park is easily accessible in only $207 \mathrm{kms}$ from Addis Ababa to shashemene road via bishoftu, Mojo, and zeway(asphalt road) and $227 \mathrm{kms}$ through Alemgena, Butajira and zeway (asphalt road and less traffic). Since the lodge is in the park, after paying an entrance fee at parks HQ one has to drive further for $82 \mathrm{kms}$ through shashemene on the way to wolayta sodo. After driving about $68 \mathrm{kms}$ on asphalt road until small local village called awara taking a turn to the right following the sign posts of the Parks and the lodge and driving on gravel road for $14 \mathrm{kms}$ will directly leads you to lodge and the third lake of the park named Chitu. The lodge is also very close to Hawassa (one hour) through shashemene.

Ecological sustainability: since proper energy utilization and wise use of available resources is one way of achieving ecological sustainability, solar energy is the main energy source of the lodge and candles are sometimes used. Clean water for the lodge is public which is transported from the City Called Shashemene. Liquid and dry wastes are separated and septic tank is used for waste treatment which can ensure the protection of the natural resources that are found in the destination. Besides, the lodge has sign posts on each turning point even if there are no directive signs inside the lodge.

Socio-cultural sustainability: staffing of the lodge includes a total of 11 employees, except the manager all the employees are from local area. Besides, ETB100 is transferred to the local community for every room rented. These can be taken as an indicator for the direct involvement of local communities in the destination as well as the direct financial benefit of the community from the eco-lodge. This shows the positive implication of the development of the eco-lodge for the wellbeing of the local community.

Economic sustainability: One must first pay an entrance fee of the park which is ETB90 (foreign tourist), ETB50 (foreign resident), ETB20 (local tourist) and ETB10 (Childers below ten years and students) excluding payment for vehicles based the number seats and tents (if any). Rates for the lodge are \$55 (single bed), \$65 (room for two) 
and $\$ 80$ (room for three) VAT and service charge are included in all prices.

\subsection{ECO-LODGE AND TOURIST INFRASTRUCTURES DEVELOPMENT AROUND ASLNP (as of 2017)}

In addition to the lodges recorded inside the park thirteen (13) Eco-lodges were located during the study. However, the survey was conducted on Eight (8) active/functioning lodges.

Table 2. Eco-lodges around Abijata Shalla Lakes National park.

\begin{tabular}{|l|l|l|l|}
\hline No & Name of the lodge & Distance from the park HQ & Status \\
\hline $\mathbf{1}$ & Simbo beach resort & $3 \mathrm{kms}$ & active \\
\hline $\mathbf{2}$ & Bishan-gari lodge & $19 \mathrm{kms}$ & Not active \\
\hline $\mathbf{3}$ & Sabana beach resort & $9.8 \mathrm{kms}$ & active \\
\hline $\mathbf{4}$ & Karkaro beach cottage & $10 \mathrm{kms}$ & active \\
\hline $\mathbf{5}$ & Langano Fil-wuha lodge & $19 \mathrm{kms}$ & active \\
\hline $\mathbf{6}$ & Africa vacation club & $14.8 \mathrm{kms}$ & active \\
\hline $\mathbf{7}$ & Langano lodge & $12 \mathrm{kms}$ & Temporarily closed \\
\hline $\mathbf{8}$ & Borati resort & $14 \mathrm{kms}$ & active \\
\hline
\end{tabular}

\subsubsection{SIMBO BEACH RESORT, LANGANO}

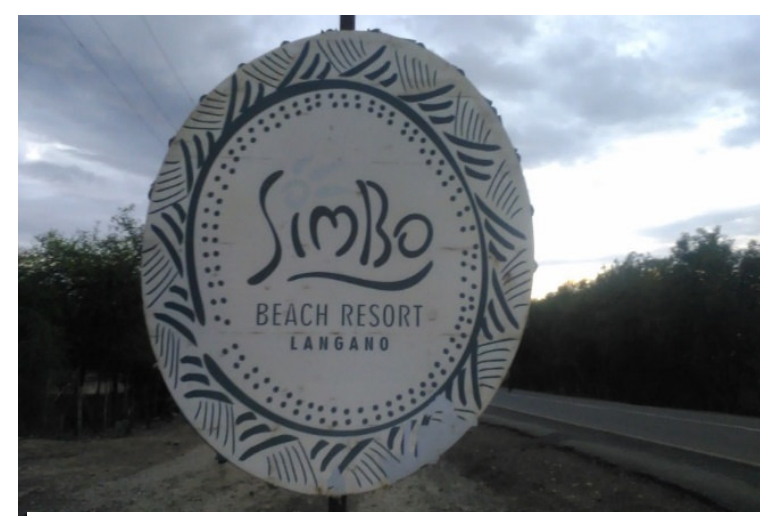

Figure 3. Main road sign post on the entrance to Simbo beach resort ( (C) Zerubabel Worku, 2017)

Simbo beach resort, Langano, is run by Ethiopian owner since 2006. The resort is one of the resorts which are found on Lake Langano and the closest of all the lodges on the area with only $3 \mathrm{~km}$ from the parks headquarter with unique $1000 \mathrm{~m}$ long fine beach sand and recommendable lake to swim.

Natural attractions and activities: this resort has a Lake as a flagship attraction which is called Langano Lake and following the presence of the Lake it is possible to have a look on the beauty of sun-rise early in the morning and its ray lying down on the lake. Besides, there are also numbers of bird species, acacia trees and land escape scenery of the surroundings is part of the breath-taking resources found in the resort. The resort offers recreational activities like: -Horse riding, boating, swimming (lake), beach volleyball and soccer and outdoor children's playing grounds, camp-fire, dinner parties, lunch buffets.

Accommodation: The resort has 74 bed rooms with 6 (six) different standards: -Bungalows, king deluxe, queen deluxe, Queen standard, double and standard rooms, 2 (two) camps, 1 (one) meeting hall, restaurant and 1 (one) TV room. Both national and international foods are available inside the resort.

Transportation: Since the resort is found on the main road from Addis Ababa to Shashemene the $207 \mathrm{~km}$ road is asphalt with only $3 \mathrm{~km}$ off-road driving. The $3 \mathrm{~km}$ gravel can road serve all over the year with small reparation on rainy season.

Ecological sustainability: it has one directory sign post on the main asphalt road right on the turning point, welcoming post at resorts entrance and different small sign posts inside the resort. Even if candles and generators are used as energy source, electricity is the main energy source for the resort, however using alternative energy sources like solar energy and biogas fuel are advisable for such eco-destinations. The resort fulfils its clean water demand by water from Dole town water supply and underground water for some purposes. Liquid and solid wastes are separated and treatment is by septic tank.

Socio-cultural sustainability: The resort has a total of 125 employees, 115 of them are employees from local community and the rest 15 are from other areas. The resort creates a great job opportunity for the locals and is benefiting them through direct participation.

Economical sustainability: $\$ 61$ week days, $\$ 68$ weekends (minimum price) and $\$ 111$ week days, $\$ 123$ weekends (for guest who need room from 2 up to 4 rooms). All rates include VAT and service charge. 


\subsubsection{SABANA BEACH RESORT, LANAGANO}

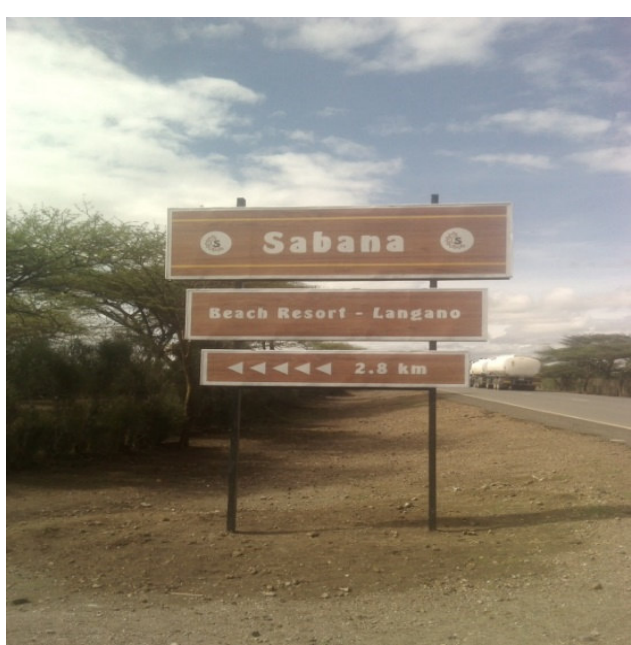

Figure 4. Main road sign post of Sabana resort (C) Zerubabel Worku, 2017)

Sabana beach resort, Langano, is a beach resort established 2007 with location only $200 \mathrm{kms}$ from Addis, at the heart of rift valley coving an area of 6 hectares. The resort is a property of Blue tops trading Plc. Sabana can be reached from Addis either through Addis Ababa-Moyale road going through Bishoftu, Mojo, and Zeway $(200 \mathrm{~km})$ or through Alemgena, Butajira and Zeway $(220 \mathrm{~km})$. The resort if found at the distance of $9.8 \mathrm{~km}$ away from the park ( $7 \mathrm{~km}$ asphalt and $2.8 \mathrm{~km}$ gravel).

Natural attractions and activities: lake, which is the major attraction of every resort that are found in the shores of Langano. Besides, birds, view of sun rise, landscape scenery, caves and trees are also the other attractions that are found in the resort which offers the following ecotourism activities for tourists. Boating, beach volleyball and football, outdoor children's playground, beach walking, bird watching, swimming (in the lake) are available activities of the resort. Massage, free baby bed, foreign currency, sleeping bags, coffee ceremony, a venue for cinema, sporting events and screening news broadcasts are also the additional activities that are provided in the resort. This resort has relatively variety of activities to engage every of their tourists in their interest, which plays a great role regarding tourist satisfaction.

Accommodation: the resort has 4 (four) villas and 25 (twenty-five) bungalows, carefully furnished with locally inspiring designs. Verandahs of all bungalows overlook the beautiful lake scenery creating the perfect atmosphere. The resort also has one fully equipped conference hall that can accommodate up to 60 peoples, one wellness center, one beach bar and one uniquely designed restaurant. Both national and international food menu are available in the resort.

Transportation: it is $202.8 \mathrm{~km}$ away from Addis Ababa through Addis Ababa-Shashemene road via Bishoftu, Mojo, and Zeway $(200 \mathrm{~km}$ asphalt and $2.8 \mathrm{~km}$ gravel) and $222.8 \mathrm{~km}$ through Alemgena, Butajira and Zeway $(220 \mathrm{~km}$ asphalt and $2.8 \mathrm{~km}$ gravel).

Ecological sustainability: electricity is the main energy source and generators are used as a back-up. Clean water is sourced from Dole town water supply office and water from the lake is also used for some purposes. Drainage system is well organized and conservation supportive, Liquid and solid wastage is separated and treatment is by septic tank, but there is no recycling at all. The resort has one attractive sign post at the turning point from the main asphalt road, welcoming post at the resorts entrance and different directive sign posts inside the resort. Besides, the activities that are offered for tourists in this resort are non-consumptive ecotourism activities in a manner that don't degrade the existing natural resources.

Socio-cultural sustainability: this resort offers a benefit for the locals through direct participation by hiring relatively the highest number of employees from the local community which has a total of 142 local employees.

Economical sustainability: \$76 and \$66 for single room (weekend and weekdays) and \$148 and \$129 family bed for five inclusive of breakfast, wellness center entrance and 15\% VAT. However, there might be some fluctuation on the financial performance of the resort since tourism sector is not dynamic throughout the year.

\subsubsection{KERKERO BEACH COTTAGE, LANGANO}

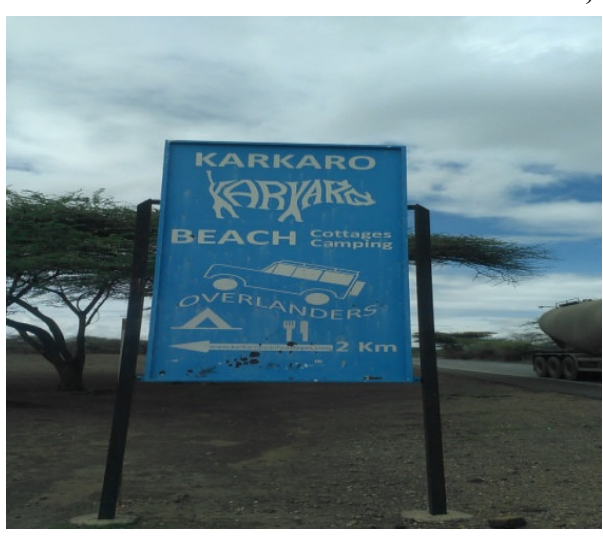

Figure 5. Entry sign post of Kerkero beach cottage (@ Zerubabel Worku, 2017)
Karkero beach cottage, langano, is a cottage founded on 1997E.C by an American owner William Cater head on the beach sands of Lake Langano. It is found $10 \mathrm{kms}$ away from the park and of this $8 \mathrm{kms}$ of the road is asphalt and $2 \mathrm{kms}$ is gravel road.

Natural attractions and activities: likewise, the natural resources that are found in this resort include the Langano Lake and the lodge is built on the shore of the lake, the view of the sun rise early in the morning, landscape scenery and variety of bird species. Following the presence of these resources the activities that are offered for tourists are boating, swimming (lake) and beach volleyball and soccer are available.

Accommodation: It has 13 (thirteen) villas for rent, one restaurant and camping is available on the selected sites of the beach. Regarding the food service any kinds of foods are available based on the interest of the guests.

Transportation: the cottage is easily accessible with only $2 \mathrm{kms}$ off 
road driving from the main road from Addis Ababa to Shashamene after 199kms.

Ecological sustainability: electricity is the main energy source and candles are used sometimes. The lake is the only water source for the cottage, the water from the lake is treated by aluminum sulfate and waste is treated by septic tank, the lodge also has drainage system to control run-off water. Relatively this resort is using some sort of the nature and doesn't produce its own energy source for the resort. The cottage has two sign posts on the main asphalt road from Addis Ababa to Shashemane with direction and information on them and some directive posts inside the cottage.

Socio-cultural sustainability: The cottage has a total of 40 workers; all are local employees where it is possible to say that the resort totally depends on the locals regarding labor resource.

Economical sustainability: tourism by its nature is a seasonal sector that the flow of tourists depends on the weather condition; especially when we come to the foreign tourists. Therefore, villas of the cottage are rented for some fixed period, as the time-period varies the rates also varies, rates for camping also varies depending size of the tent, number guests and season.

\subsubsection{AFRICA VACATION CLUB, LANGANO}

Africa vacation club resort is a private lodge which is established on 2010 by Italian owner Sonia Pangua on the shore of Lake Langano with fine and suitable beach sand for different recreational purposes. The services provided and its organization makes the lodge one of the best choices by guests all around the world. The lodge is $14.8 \mathrm{kms}$ far away from the park with $12 \mathrm{kms}$ asphalt and $2.8 \mathrm{kms}$ gravel road.

Natural attractions and activities: the combination of the lake view with the beautiful looking sunrise, the land escape scenery and the fascinating sounds of variety of bird species and beach sand have the breath-taking beauty together. Depending on the presence of these resources the following recreational activities are currently available in the resort. The recreational activities include swimming, boating, horse riding, beach volleyball and soccer, kayaking, ping pong, billiard, jotteni, basketball, sack race and egg race, kids club, outdoor children's playground, jumper and kid's jungle.

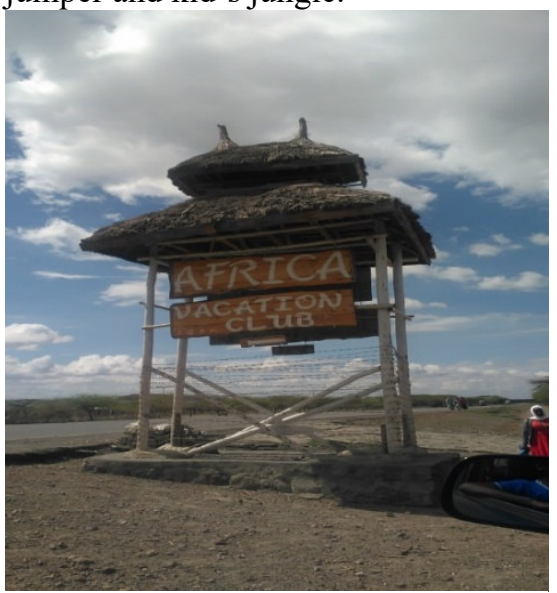

Figure 6. Main sign post of Africa vacation club (C Zerubabel Worku, 2017)
Accommodations: the lodge has rooms in 4 (four) types and extra bed on demand the bedrooms are Tukul village bungalows up to 4 peoples, villa lake front up to 6 peoples, suite lake view couple and standard room garden view couple. There is also one hall for conference, private party and DSTV, spa and sale point. Both national and international foods are available in the resort which can be served based on the interest of tourists. Transportation: one can get to Africa vacation club by driving $195 \mathrm{~km}$ on the main asphalt road from Addis Ababa to Shashemene and $2.8 \mathrm{~km}$ off road driving on gravel road which directly leads to the lodge.

Ecological sustainability: electricity is the main energy source; generators are used as a back-up and candles on dinners and spa rooms. Clean water source for any service activities is owned by public from Goljota area and lake water is sometimes also used after chemically treated. The lodge has drainage system to manage run-off water, waste is treated by septic tank and swimming pool water is recycled. The lodge has one sign post on the main road, welcoming post at the main gate and well-organized directive sign post inside the compound.

Socio-cultural sustainability: the lodge has a total of 140 employees, of which 125 of them are employees from local area and 15 employees from other places. Employees from other places are necessary for having well trained and qualified for service quality.

Economical sustainability: as the entire lodges of the area the rate varies based on room type and capacity to carry number of tourists at a time.

\subsubsection{LANGANO FIL-WUHA LODGE, LANGANO}

Langano fil-wuha lodge, langano, is the only governmentally administered lodge that is surveyed.Even if there a controversy on the year of its establishment 1974 the lodge believed to be the first lodge on Lake Langano. The lodge is $19 \mathrm{kms}$ away from the parks headquarter with $16 \mathrm{kms}$ asphalt and $3 \mathrm{kms}$ gravel road.

Natural attractions and activities: likewise, the natural resources that are found in this lodge are also like the other resorts that are found around the ASLNP. These are the lake, variety of birds; sand beach, sun rise and land escape scenery. The activities that are offered in this lodge are when compared to other lodges on the area the lodge has a major drawback on activities it offers that is beach volleyball and soccer with private boating.

Accommodations: the lodge has 30 (thirty) standard single bed rooms and 10 (ten) bungalows, 1 (one) meeting hall and camping is available. Regarding the food service, both national and international foods are available for tourists.

Transportation: as all resorts around Lake Langano the main asphalt road from Addis Ababa-Shashemene leads to the lodge's turning point after $191 \mathrm{kms}$ driving. By turning to the left and driving $3 \mathrm{kms}$ further on gravel road 
will directly leads you to the lodge.

Ecological sustainability: electricity, generators and candles are energy sources for the lodge. The water source for the lodge was water from the lake but now the lodge is using public water. The lodge has drainage system, solid and liquid waste is separated and treated by septic tank but there is no recycling at all. The lodge has the biggest sign post from other lodges of the area on the turning point from main road and different posts inside the lodge.

Socio-cultural sustainability: totally there are 86 employees in the lodge with 84 from local area and the rest 2 from other places.

Economical sustainability: rates vary from a minimum of $\sim \$ 39$ for single bed up to $\sim \$ 110$ for bungalows.

\subsubsection{BORATI RESORT, LANGANO}

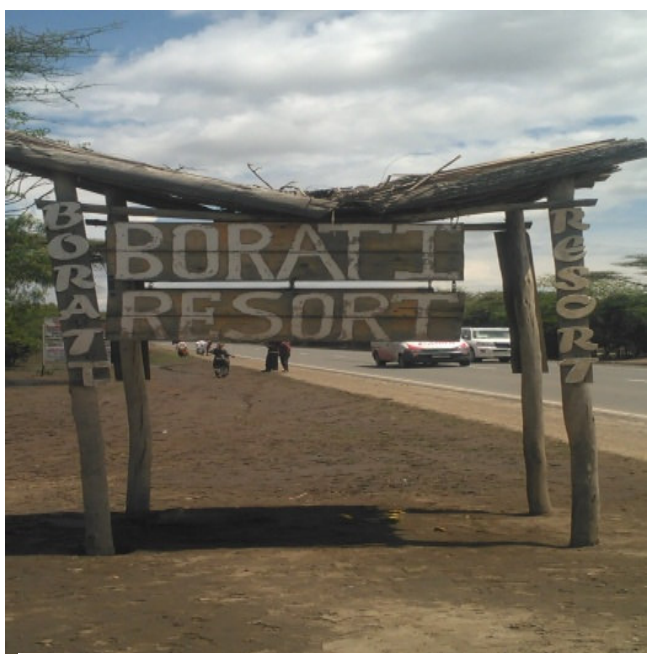

Figure 7. Entry sign post of Borati resort (@ Zerubabel Worku, 2017)
Borati resort, langano, is a beach resort which is established on 2003 on the shores of Lake Langano by the owner Ato Getahun Asfaw. Along the road one can see beautiful land escapes, at Borati resort a paradise for holyday makers, there is tradition for most vacationers include setting up tents along beach and eating fresh meat (barbeque). The resort is found at $14 \mathrm{kms}$ from the head quarter (11 kms asphalt and $3 \mathrm{kms}$ gravel road).

Natural resources and activities: this resort has relatively additional and variety of natural resources than the other ones. These include the Langano Lake, caves, mountains, variety of birds and sun rise. Having these resources, the following ecotourism activities are offered in the resort; boating, swimming (lake), beach volley ball and soccer and outdoor children's play grounds, beach walks and bird watching are available.

Accommodations: the resort has four family standard rooms, one bungalow, five double bed rooms and four twin standard beds. In addition, camping is available in the resort. Both the national and international foods are available for the sake of accommodating all types of tourists. Besides, beach barbeque is also provided in this resort.

Transportation: the resort is located $199 \mathrm{kms}$ south of Addis Ababa with 196kms asphalt and $3 \mathrm{kms}$ gravel road. Ecological sustainability: electricity is the main energy source and generators are used as a backup and candles sometimes. As most of the lodges at the area source of fresh water for this lodge is public water even if lake water with chemical treatment is sometimes used. Septic tank is used for treatment of waste and drainage is managed by the lodge. There is sign which directs to the lodge with the necessary message on the main asphalt road and their directive posts inside the lodge.

Socio-cultural sustainability: the resort has a total of 32 employees ( 31 local employees and 1 employee from other area). Where the major source of labor is from the surrounding that implies the great concern given for the local community.

Economical sustainability: $\$ 39$ for single bed room, $\sim \$ 50$ for double beds and twin bed rooms, $\sim \$ 98$ for family bed rooms, $\sim \$ 145$ for bungalows (three bed rooms) and $\sim \$ 20$ for tents. Except for tents rates are inclusive of breakfast.

\section{CONCLUSION AND RECOMMENDATION}

The evaluation on development of destinations was done from being in line with one of the basic principle of ecotourism; sustainability. This was achieved through examining the features that the destinations possess as an indicator. Some of the indicators that can be taken as features of eco-lodges are destinations with due care for nature, benefits the locals, eco-friendly infrastructures, quality service provision, activities to be carried out, the main aim of the destination regarding their concern about natural resource conservation and proper sewerage system. Eco-lodges are an exciting and potentially extremely viable strategy for achieving all the tenants of ecotourism, and more specifically community based eco-tourism. The high number of eco-lodges and nature-based lodges located in or near protected areas, or areas of high biodiversity value, demonstrates the need for lodges to maintain sound environmental standards and practices.

All the surveyed lodges are found in $22 \mathrm{kms}$ radius from Abijata shalla lakes national park, except one lodge which is found in $82 \mathrm{~km}$ away from the head quarter of the park. Of the 7 (seven) lodges surveyed six of them (Simbo beach resort, Sabana beach resort, Karkaro beach cottage, Langano Fil-wuha lodge,Africa vacation club and Borati resort) are found surrounding lake langano near to ASLNP and one lodge (10,000 flamingos lodge) is inside the park. From the surveyed 7 (seven) lodges, 6 six (Simbo beach resort, Sabana beach resort, Karkaro beach cottage, Langano Fil-wuha lodge, Africa vacation club and Borati resort) of them can be reached with only 
3 (three) kilo meters off road driving on gravel road and the rest two in 14 and $17 \mathrm{kms}$ off road driving $(10,000$ flamingos lodge and Bishan-gari lodge). As discussed on the result the eco-lodges which are currently at operational phase are only 7 in number and of these only 10,000 Flamingos lodge is in the ASLNP whereas the rest 6 eco-lodges are found between $3 \mathrm{~km}$ to $19 \mathrm{~km}$ far away from the park.

Each of the eco-lodges bases their establishment using the Langano Lake as a flagship attraction. Besides, almost all the eco-lodges have the similar resources which are; the Lake, birds, landscape scenery, and of course the sunrise view. However, the type of activities they developed makes them different from one another. For instance, Borati resort has variety of resources than other eco-lodges possess such mountains and cave. Whereas, Sabana beach resort has developed variety of ecotourism activities than the other surveyed eco-lodges which need to be encouraged since it plays a great role regarding customer satisfaction. Staffing in the surveyed lodges of the area is also participatory of the local community, from 630 the total employees the lodges has $597(94.76 \%)$ are employees from the local areas and only 33 (5.24\%) employees from other places. This implies the resorts are involving the locals in the development of the resort and is in line with one of the principle of ecotourism which is benefiting local communities and is one way of achieving.

From the surveyed eco-lodges only 1000 flamingos use solar energy as energy source for the lodge. Whereas, the others are dependent on the electricity as the main energy source and candle is an optional light for rooms and restaurants. However, generating optional energy source through using proper utilization of resources like recycling is recommendable for achieving sustainability. In relation to clean water and sanitation, majority of the eco-lodges use water from the surrounding public while treating the lake water and using it for some cases. Especially, Kerkero beach cottage totally depends on the lake water by applying chemicals for use. All destinations use septic tanks for waste disposal and treatment. However, recycling of wastes for another use is not adopted by any of the resorts. Besides, almost all the destinations have a sign post on the main asphalt and on different directions of the inside.

\section{REFERENCES}

Adem Gobena. 2008. Assessment of Ecotourism Potentials for sustainable natural Resources Management in and Around ASLNP in the Central Ethiopian Rift Valley, an MSc thesis, Addis Ababa University, Ethiopia.

Africa vacation club- langano. 2017. Retrieved from: www.africavacationclub.com.et

Amare Alemneh. 2015. Wildlife Resources of Ethiopia: Opportunities, Challenges and Future Directions: From Ecotourism Perspective: A Review Paper. Natural Resources, 6, 405-422. http://dx.doi.org/10.4236/nr.2015.66039

Astella, B.A., van der Duim, V.R. and Duineveld, I.M.M., 2013. Multiple Enactments of Abijata Shalla Lakes National Park, Ethiopia.

Ayenew, T., 2001. Numerical groundwater flow modeling of the Central Main Ethiopian Rift lakes basin. SINET: Ethiopian Journal of Science, 24(2), pp.167-184.

Conservation International. 2017. Retrieved from: www.biodiversityhotspots.org.

Ethiopian Wildlife and Natural History Society (EWNHS). 1996. Important Bird Areas of Ethiopia: A First Inventory. Ethiopian Wildlife and Natural History Society, Addis Ababa, pp.55-60.

Fekadu Tefera, and Rezenom Almaw. 2002. Major attractive fauna bird species of Abijata Shalla Lakes National Park. Addis Ababa, Ethiopia.

Feyera Senbeta and Fekedu Tefera. 2001. Environmental Crisis in Abijata-Shala Lakes National Park. Walia, 22(3):29-34

Hirut Sintayehu. 2012. Problems and prospects of developing bird watching tourism, the case of Abijata shalla lakes national park. Ethiopia. Pp177.

International Environmetrics Society (TIES). 2004. International Symposium on Spatial Accuracy Assessment in Natural Resources and Environmental Sciences (The 15th Annual TIES Conference). Portland, ME, USA

Regassa, T.O.L.C.H.A., 2005. An ecological study of vegetation around Lake Abijata (Doctoral dissertation, MSc. thesis, Addis Ababa University, Addis Ababa).

Rezenom Almaw. 2012. A Checklist of the Birds of the Abijata-Shalla Lakes National Park. Ethiopian wildlife conservation authority, Addis Ababa, Ethiopia.

Sabana beach resort- langano. 2017. Retrieved from: www.sabanalangano.com

Simbo beach resoprt- langano. 2017. Retrieved from: www.simbobeachlangano.com

The International Ecotourism Society (TIES) 2004. Eco-lodge footprint and justification for biodiversity conservation, January 2004, Available at: www.ifc.org/ebfp.

The nature conservancy. 2002. Results of the eco-tourism program's conservancy member's eco-traveler survey, September 2002, available at: www.nature.org.

World Tourism Organization (UNWTO). 2011. Tourism Highlights (2011 Edition). Spain: Madrid. 